\title{
THE PREDICTORS OF STUDENTS' ATTITUDE TOWARDS INCLUSION OF CHILDREN WITH DISABILITIES IN PHYSICAL EDUCATION CLASSES
}

\author{
Ana Orlić, Bojan Pejčić, Dušanka Lazarević, Ivana Milanović \\ University of Belgrade, Faculty of Sport and Physical Education, Serbia
}

\begin{abstract}
Positive attitude towards inclusion of children with disabilities in Physical Education (PE) classes is one quite important factor for successful implementation of inclusive education. The aim of this study was to examine the predictors of attitude of the students as future PE teachers towards inclusion in PE. In this study, the predictors in the field of personality, professional competences for working with children with disabilities and certain personal characteristics (gender) were included. The sample included 221 students of the final year of studies at the Faculty of Sport and Physical Education in Belgrade, Niš and Novi Sad. In order to measure the attitude towards inclusion in PE, the instrument of Attitude Toward Inclusive Physical Education was used. In the field of personality, a trait of openness to experience was examined, which was measured using the HEXACO PI-R instrument. An additional questionnaire was also designed by which the students were asked to indicate their gender and professional competences for working with children with disabilities: their average mark during the studies, subjective assessment of the level of knowledge and skills required for working with children with disabilities acquired in the course of their studies (self-assessment of professional competence) and experience in working with children with disabilities during their professional practice. The results of multiple regression analysis showed that openness to experience, self-assessment of professional competence and gender were significant predictors. The results indicate that, during the training for teaching profession, it is necessary to develop students' specific competences required for the work in inclusive education as well as to create the teaching atmosphere which will enhance inquisitiveness and creativity as significant determinants of the trait of openness to experience.
\end{abstract}

Key words: EDUCATION / PERSONALITY / COMPETENCES / STUDENTS

\section{INTRODUCTION}

Teachers' positive attitude towards inclusion of children with disabilities in regular classes is one of the most important factors for quality implementation of inclusive education (Avramidis, \& Norwich, 2002; Brojčin, 2013; O’Brien, Kudláček, \& Howe, 2009). Teachers' attitudes influence both communication processes in the class and the quality of realization of teaching contents prescribed by the curriculum (Logan, \& Wimer, 2013). The studies have shown that the PE teachers who have positive attitudes towards inclusive education put more effort into teaching process which results in the improved development of children with disabilities (Elliott, 2008). Therefore, it is very important to develop positive attitudes toward inclusive education with students as future holders of inclusive process.

Although there are various concepts of attitudes in psychology, the authors agree that they represent dispositions which may be formed and changed under the influence of different personal and social factors (e. g., Vogel, \& Wanke, 2016). Hutzler (2003) has shown, in his review study, that gender, previous experience in working with children with disabilities and perceived competence for the implementation of inclusive education were most frequently examined factors related to the PE students and teachers' attitudes towards inclusion.

The studies dealing with the relationship between gender and attitude towards inclusion in PE have not 
presented consistent results. A number of studies have shown that female PE students and teachers had more positive attitudes towards inclusion than male PE students and teachers (Downs, \& Williams, 1994; Folsom-Meek, Nearing, Groteluschen, \& Krampf, 1999; Hodge, \& Jansma, 2000; Hutzler, Zach, \& Gafni, 2005; Papadopoulou, Kokaridas, Papanikolaou, \& Patsiaouras, 2004), whereas, in certain studies, there were no gender differences (Doulkeridou, Evaggelinou, Mouratidou, Koidou, Panagiotou, \& Kudlacek, 2011; Pejčić, Orlić, \& Milanović, 2016; Rizzo, \& Vispoel, 1991; Tubić, \& Đorđić, 2012). Although, in literature, there are few explanations for the obtained gender differences, some authors believe that a possible reason could be in the fact that men are more oriented towards training than to teaching process, which may cause a role conflict when including children with disabilities in PE classes, which further leads to forming negative attitudes towards inclusion (Hutzler et al., 2005).

The authors agree that perceived competence for working with children with disabilities is one of the most important factors associated with attitudes towards inclusive education (Block, \& Rizzo, 1995; Hutzler, 2003; Kowalski, \& Rizzo, 1996; Rizzo, \& Vispoel, 1991). The research conducted by Kowalski \& Rizzo (1996) using regression analysis has shown that perceived competence is the most important predictor of positive attitudes towards inclusive PE, followed by a number of university courses devoted to inclusive education as an important predictor as well. Comparable results were obtained also by Hutzler et al., (2005) who have shown that positive attitudes towards inclusion are associated with a greater perception of self-efficacy in teaching children with disabilities in PE classes. Although the sources of perceived competence, as a complex psychological construct, may vary, it has been shown that good preparation of the PE students during educational process increases the perception of competence and confidence in their own abilities in order to implement inclusive education successfully (O'Brien et al., 2009).

The studies dealing with personal experience in working with children with disabilities as a factor related to attitudes towards inclusive PE obtained contradictory results. In some studies it has been shown that the teachers or students who have been experienced in working with children with disabilities have more positive attitudes (Folsom-Meek et al., 1999), in some studies it has been shown that they have more negative attitudes (Downs, \& Williams, 1994; Pejčić et al., 2016), while certain studies did not show any relationship between experience and attitudes towards inclusion at all (Hutzler et al., 2005; Tubić, \& Đorđić, 2012). The authors believe that the main reason for inconsistent results may be found in the quality of experience which the teachers or students acquired during their inclusive practice: if it is perceived that teaching process is under control and if it results in positive learning outcomes the attitudes become more positive, and if it is perceived that teaching process is not under control, the attitudes remain unchanged or become even worse (Hutzler et al., 2005).

Previous studies did not link attitudes towards inclusion of children with disabilities with personality structure. However, in many studies, it has been shown that personality structure is an important determinant for developing attitudes and prejudices. Personality trait which has shown a consistent relationship with different types of attitudes is openness to experience. In modern theories, this trait is considered one of the basic personality traits and as such it is recognized in both five-factor personality model (Costa, \& McCrae, 1995), and HEXACO model as well (Lee, \& Ashton, 2004). Openness to experience in its positive dimension includes inquisitiveness, creativity, unconventionality and aesthetic appreciation, whereas in its negative dimension it includes conventionality, orientation towards traditional attitudes and beliefs, preference for known over unknown, rejection of new concepts and ideas and a lack of aesthetics (e. g., Lee, \& Ashton, 2004). In his extensive research, Saucier (2000) has shown that openness to experience is associated with a wide range of social attitudes. Specifically, it has been shown that the people closed to experience are prone to right-wing authoritarianism (RWA) and social dominance orientation (SDO) as well as to prejudices towards minority groups which are perceived as dangerous, derogated or different in relation to the majority (Sibley, Harding, Perry, Asbrock, \& Duckitt, 2010). The authors believe that closure to experience affects that the world around us is perceived as a source of new, unknown and risky ideas threatening to jeopardize stability, which is suitable for the development of right-wing authoritarianism and social dominance orientation. As a result, negative attitudes and prejudices towards different types of minority groups have been developed (Sibley et al., 2010; Sibley, \& Duckitt, 2013). Bearing this in mind, it is reasonable to assume that this personality trait 
may be also related to attitudes towards inclusion of children with disabilities in PE classes.

The aim of this study was to examine the predictors of attitudes of the students as future PE teachers towards inclusion of children with disabilities in physical education classes. The predictors in the field of personality, professional competences for working with children with disabilities and certain personal characteristics (gender) were included. The predictor in the field of personality was a trait of openness to experience. Professional competences for working with children with disabilities were examined through the students' average mark in the course of their studies, subjective assessment of the level of knowledge and skills required for working with children with disabilities acquired during the studies (self-assessment of professional competence) and experience in working with children with disabilities.

\section{METHOD}

\section{Participants}

The sample of this research included 221 students of the final year (the fourth year of academic and master degree studies) at the three Faculties of Sport and Physical Education in Serbia. The sample included 99 (44.8\%) students from Belgrade, 58 (26.2\%) students from Nis and 64 (29\%) students from Novi Sad. According to gender, the sample included 128 (57.9\%) male students and 93 (42.1\%) female students.

\section{Instruments and variables}

In order to measure the students' attitudes towards inclusion of children with disability in Physical Education classes the instrument Attitude Toward Inclusive Physical Education - ATIPE (Hutzler et al., 2005) was used, and it was adapted by Đorđić et al. for the purposes of the research in Serbian. This instrument consisted of 15 items accompanied by a fourpoint Likert type scale. The factor structure of the instrument (analysis of the main components) used in this research showed a one-factor solution which explained $39 \%$ of variance, justifying the overall score on the scale. The score on ATIPE scale is expressed by the mean value of the responses to all the items, and a higher score indicates more positive attitudes towards inclusion of children with disability in $\mathrm{PE}$ classes. Reliability of the instrument (Cronbah $\alpha$ ) in this study was .87 .

Openness to experience was measured using the instrument HEXACO PI-R (Lee, \& Ashton, 2004). A sub-scale measuring this trait consisted of 16 items including four fields: aesthetic appreciation, inquisitiveness, creativity and unconventionality. Each item was accompanied by a five-point Likert type scale. The score was expressed by the average value of responses to all the items, and a higher score indicates a greater openness to experience. Cronbah $a$ measure of reliability in this study was .81 .

A questionnaire was designed to collect general information about the subjects (gender, place and year of studies) and their professional competence for working with children with disabilities. The students' professional competences were assessed through their success during the studies, subjective assessment of the level of knowledge and skills required for working with children with disabilities that they have acquired in the course of their studies (self-assessment of professional competence) and through the experience in working with children with disabilities. The students' performance during the studies was operationalized by their average mark. Self-assessment of professional competence was measured by the following question:"Please, rate the extent of your knowledge and skills required for working with children with disabilities that you have acquired during previous education on a scale from 1 to 5 ", where 1 meant that they have acquired no knowledge or skills and 5 meant that they have acquired all the required knowledge. The experience in working with children with disabilities was measured by the following question:" Have you ever, during your professional practice or other activities at your faculty, had a chance to work in a class including a child with disability?", where the students responded with YES or NO.

\section{Procedure}

Filling in the questionnaire lasted between 10 and 15 minutes. The participation in this research was voluntary and anonymous.

\section{Statistical analysis}

The data were processed by descriptive analysis (arithmetic mean, standard deviation, minimum and maximum value, frequency, percentage) and by concluding statistics (regression analysis). 


\section{RESULTS}

Table 1 shows the results of descriptive statistics (minimum, maximum, arithmetic mean and standard deviation) for individual items of the
ATIPE scale. The presented data have been presented in non-recoded values. In further analyses, the items formulated in negative forms were recoded so that a higher score indicates a more positive attitude.

Table 1. Descriptive statistics for individual items of the ATIPE scale

\begin{tabular}{|c|c|c|c|c|}
\hline Item & Min & Max & M & SD \\
\hline $\begin{array}{l}\text { The PE teacher doesn't have knowledge and skill to teach a } \\
\text { child with sensorimotor disability. }\end{array}$ & 1 & 4 & 2.57 & 0.99 \\
\hline $\begin{array}{l}\text { One shouldn't include a child with disability in the class because } \\
\text { his/her image is disgusting. }\end{array}$ & 1 & 4 & 1.97 & 0.97 \\
\hline $\begin{array}{l}\text { Since excellence is a major requirement, it is important to avoid } \\
\text { any disturbance to the PE class, such as inclusion of children } \\
\text { with disability. }\end{array}$ & 1 & 4 & 2.41 & 0.90 \\
\hline Children with disability can profit a lot from PE classes. & 1 & 4 & 3.26 & 0.83 \\
\hline $\begin{array}{l}\text { Children with disability often cause discipline problems during } \\
\text { PE classes. }\end{array}$ & 1 & 4 & 2.14 & 0.98 \\
\hline $\begin{array}{l}\text { A teacher who includes a child with disability in the class will } \\
\text { reduce the amount of time devoted to all the other children. }\end{array}$ & 1 & 4 & 2.84 & 1.02 \\
\hline A child with disability could slow the learning of his/her peers. & 1 & 4 & 2.60 & 1.06 \\
\hline A child with a disability is a threat to the PE teacher. & 1 & 4 & 2.28 & 0.89 \\
\hline Children with disabilities should be taught in special classes. & 1 & 4 & 2.79 & 0.95 \\
\hline $\begin{array}{l}\text { Including a child with a disability is a personal challenge for the } \\
\text { PE teacher. }\end{array}$ & 1 & 4 & 2.98 & 0.83 \\
\hline $\begin{array}{l}\text { A teacher who includes a child with disability is at risk of more } \\
\text { stress. }\end{array}$ & 1 & 4 & 2.96 & 0.93 \\
\hline $\begin{array}{l}\text { Including a child with disability could enhance democratic and } \\
\text { pluralistic values. }\end{array}$ & 2 & 4 & 3.31 & 0.68 \\
\hline $\begin{array}{l}\text { Including a child with disability in the class creates frustration } \\
\text { and embarrassment. }\end{array}$ & 1 & 4 & 2.14 & 0.74 \\
\hline $\begin{array}{l}\text { The regular class can profit from the inclusion of a child with } \\
\text { disability. }\end{array}$ & 1 & 4 & 2.57 & 0.88 \\
\hline $\begin{array}{l}\text { It is not appropriate to ask a teacher who is supposed to take a } \\
\text { whole class to pay attention to the special needs of a disabled } \\
\text { child and his/her family. }\end{array}$ & 1 & 4 & 2.72 & 1.06 \\
\hline
\end{tabular}

Note: Min - minimum, Max - maximum, M - Mean, SD - standard deviation

Table 2 shows descriptive indicators for the entire ATIPE scale, openness to experience, average mark during the studies and self-assessment of the level of knowledge and skills required for working with children with disabilities. The obtained values of standardized skewness and standard kurtosis have shown that there was no significant deviation from the normal distribution for all the specified variables. When asked about their experience in working with children with disabilities 127 (57.5\%) subjects answered that they had some experience in working with these children, while $94(42.5 \%)$ subjects said they did not have any such experience. 
Table 2. Descriptive statistics for attitude towards inclusion, openness to experience, average mark during the studies and self-assessment of professional competence

\begin{tabular}{lccccccc}
\hline & N & Min & Max & M & SD & z Sk & z Ku \\
\hline Attitude (ATIPE) & 221 & 1.73 & 4.00 & 2.92 & 0.46 & -0.03 & -0.02 \\
Openess to experiences & 221 & 1.94 & 4.88 & 3.63 & 0.61 & -0.04 & -0.11 \\
Average mark & 221 & 6.00 & 9.00 & 7.91 & 0.65 & 0.00 & -0.12 \\
Self-assessment of professional competence & 221 & 1.00 & 5.00 & 2.64 & 1.02 & 0.02 & -0.24 \\
\hline
\end{tabular}

Note. $N$ - sample size, Min - minimum, Max - maximum, $M$ - mean, $S D$ - standard deviation, $z S k$ - standardized skewness, $z \mathrm{Ku}$ - standardized kutrosis

Multiple regression analysis (enter) was performed where attitude towards inclusion was a criterion variable, and openness to experience, average mark during the studies, experience in work with children with disabilities, self-assessment of professional competence for inclusive education and the subjects' gender were predictor variables. The results have shown that the regression function was statistically significant, $R$ $=.38, R^{2}=.14, F(5,215)=7.07, p<.01$, and open- ness to experience, self-assessment of professional competence and gender were pointed out as significant predictors (Table 3). Openness to experience and self-assessment of professional competence were in a positive correlation with attitude towards inclusion, whereas a sign of the partial correlation $(\beta)$ between gender and attitude towards inclusion indicates that male subjects had more positive attitudes towards inclusion than female ones.

Table 3. Multiple regression analysis - partial correlation and significance of the predictors of attitude towards inclusion of children with disabilities in PE classes

\begin{tabular}{lccc}
\hline Predictors & $\boldsymbol{\beta}$ & $\mathbf{t}$ & $\mathbf{p}$ \\
\hline Openess to experiences & .14 & 2.12 & .04 \\
Average mark & -.03 & -0.52 & .61 \\
Work experience & .10 & 1.5 & .14 \\
$\begin{array}{l}\text { Self-assessment of professional } \\
\text { competence }\end{array}$ & .29 & 4.24 & .00 \\
Gender & -.14 & -2.03 & .04 \\
\hline
\end{tabular}

Note. Codes for gender: 1 - male, 2 - female. Codes for work experience: 1 - yes, 2 - no.

\section{DISCUSSION}

The authors who deal with inclusive education agree that teachers' positive attitude towards inclusion of children with disabilities in regular classes is one of the essential factors for successful implementation of this process (Avramidis, \& Norwich, 2002; Brojčin, 2013; O’Brien et al., 2009). Regarding that attitudes represent psychological dispositions that may be formed and changed under the influence of numerous factors, different studies in the field of PE have dealt with determining the factors related to teachers and students' attitudes towards inclusive education. The results of these studies have shown inconsistent findings. Bearing this in mind, the main aim of this research was to examine the predictors of attitudes of the students as future holders of inclusive process towards inclusion of children with disabilities in PE classes.

The results of descriptive statistics have shown that the students expressed moderately positive attitudes towards inclusion of children with disabilities in PE classes, which is in accordance with the results of previous studies where the ATIPE scale was used and that were conducted in students (Tubić, \& Đorđić, 2012), PE teachers (Tubić, \& Đorđić, 2012; Pejčić et al., 2016) and teachers (Đorđić et al., 2014). Descriptive indicators of the responses to individual questions of the ATIPE scale have shown that the students mostly agreed with the statements that emphasize positive values of inclusion and the benefit that children with disabilities may obtain by their inclusion in 
regular teaching process. However, the students also agreed with those statements that emphasize a lack of time and resources required for the quality work in a class including a child with disability. These results are also consistent with the results of previous studies which have shown that PE teachers generally support a concept of inclusion, but they point out a lack of time and resources as the main obstacle for the implementation of inclusive programs (Block, \& Obrusnikova, 2007; O’Brien et al., 2009, Pejčić et al., 2016; Scruggs, \& Mastropieri, 1996).

In this research, the predictors of students' attitudes towards inclusion of children with disabilities in PE classes included the field of basic personality structure (a trait of openness to experience), professional competences for working with children with disabilities (average mark during studies, self-assessment of professional competence and experience in working with children with disabilities) and certain personal characteristics of the students (gender). Multiple regression analysis has shown that significant predictors of the students' attitudes are: openness to experience, self-assessment of professional competence and students' gender.

Previous studies have not linked attitude towards inclusion of children with disabilities in PE classes and personality structure. The results of this research have shown that openness to experience, defined by HEXACO model (Lee, \& Ashton, 2004), was a significant predictor of positive attitude towards inclusion. This result is consistent with the results of the studies that showed that a negative dimension of this trait, i.e. closure to experience, is related to a tendency to develop prejudices and negative attitudes towards different minority groups, including the groups that are perceived as derogated and rejected by social community (Sibley et. al., 2010). According to the authors, closure to experience affects the fact that the world around us is perceived as a source of new ideas threatening to jeopardize stability of the current order, which results in the development of right-wing authoritarianism and social dominance orientation, and thus, negative attitudes towards minority groups (Sibley et. al., 2010). The results of this study indicate that basic personality structure should also be considered when discussing the constituent elements of attitude towards inclusion. Although personality structure is not directly subject to pedagogical interventions, it is still possible to create the atmosphere that enhances students' inquisitiveness and creativi- ty i.e. the traits essential for openness to experience, during teaching process. In the future, studies should also examine predictive value of other personality traits which could be significant for creating positive attitudes towards inclusion, such as agreeableness.

In this study, professional competences of the students as future PE teachers were operationalized by their average marks during the studies, self-assessment of professional competence and experience in working with children with disabilities during their previous professional practice. The results have shown that self-assessment of professional competence was the only significant predictor from this group of variables. The students who assessed that they have acquired enough knowledge and skills required for working with children with disabilities expressed more positive attitudes towards inclusive physical education. It is important to note that self-assessment of professional competence had the greatest partial correlation with attitude towards inclusion in relation to all the examined variables, i.e. it is the most significant predictor of attitude towards inclusion of children with disabilities in PE classes. These results are consistent with the results of previous studies which have indicated that the perceived professional competence for working with children with disabilities is of utmost importance for forming positive attitudes towards inclusion in PE classes (Block, \& Rizzo, 1995; Hutzler, 2003; Kowalski, \& Rizzo, 1996; Rizzo, \& Vispoel, 1991). The finding that attitude towards inclusion was not associated with the average mark during the studies indicates that general educational competences are less important for developing positive attitude towards inclusion of children with disabilities in $\mathrm{PE}$ classes than the development of specific competences required for the work in inclusive education. The results of the studies showing that positive attitude towards inclusion of children with disabilities in $\mathrm{PE}$ classes is associated with a number of university courses for students devoted to inclusive education (Block, \& Rizzo, 1995) and professional training for teachers (Avramidis, Bayliss, \& Burden, 2000a,b) also support this conclusion. The authors believe that, during the preparation for inclusive teaching process, in addition to theoretical knowledge, it is very important to provide the students with practical examples and recommendations, regarding the type and degree of a child's disability (Hutzler, 2003).

Experience in working with children with disabilities in PE classes acquired by the students during 
their professional practice was not indicated as a significant predictor of attitude towards inclusion. Previous studies dealing with personal experience as a factor which may affect attitudes towards inclusive PE have not obtained consistent results. Some studies have shown that personal experience in working with children with disabilities is associated with more positive attitudes towards inclusive PE (Folsom-Meek et al., 1999), some studies have shown that it is in correlation with more negative attitudes (Downs, \& Williams, 1994; Pejčić et al., 2016), while a number of studies have not shown any relationship between experience and attitude towards inclusion at all (Hutzler et al., 2005; Tubić, \& Đorđić, 2012). Some authors believe that such inconsistent findings reflect differences in the quality of experience acquired by the teachers and students during their work with children with disabilities, which is reflected in a level of the perceived control over teaching process and the learning outcomes that result from it (Hutzler et al., 2005). Bearing this in mind, future studies should examine, in more detail, a role of personal experience in forming attitude towards inclusion in PE classes, taking into account the quality of teaching process in working with classes including children with disabilities.

Previous studies dealing with the relationship between the gender of teachers and students and their attitudes towards inclusive PE have shown that women have more positive attitudes than men (Downs, \& Williams, 1994; Folsom-Meek et al., 1999; Hodge, \& Jansma, 2000; Hutzler et al., 2005; Papadopoulou et al., 2004), or that there was no correlation between gender and attitudes (Doulkeridou et al., 2011; Pejčić et al., 2016; Rizzo, \& Vispoel, 1991; Tubić, \& Đorđić, 2012). Contrary to these findings, in this research it has been shown that male students expressed more positive attitudes towards inclusion in $\mathrm{PE}$ classes compared to female students. Since it is the first finding of this kind, the obtained results should be verified in further studies.

\section{CONCLUSION}

The results of this study have shown that the students as future PE teachers expressed moderately positive attitudes towards inclusion of children with disabilities in PE classes, but also that there is a space for further improvement. Openness to experience, self-assessment of professional competence for working with children with disabilities and gender were found significant predictors of attitude towards inclusion. Regarding that self-assessment of professional competence for working in inclusive education is the most significant predictor of the attitude, it is necessary to develop specific competences required for working with children with disabilities in PE classes, during the process of students' preparation for future educational work. In addition to theoretical knowledge of inclusive education the students should be provided with practical examples and appropriate methods for working with children with disabilities, taking into account the specificities of physical education teaching. Additionally, bearing in mind the significance of openness to experience for forming students' positive attitude towards inclusive physical education, it is necessary to create the teaching atmosphere which will enhance students' inquisitiveness and creativity.

The paper is a part of the project "Effects of applied physical activity on locomotor, metabolic, psychosocial and educational status of population of the Republic of Serbia" (No III-47015) and "Identification, measurement and development of cognitive and emotional competences significant to the society oriented towards European integration" (No. 179018), the realization of which is financed by the Ministry of Education, Science and Technological Development of the Republic of Serbia. 


\section{REFERENCES}

1. Avramidis, E., \& Norwich, B. (2002). Teachers' attitudes towards integration/inclusion: A review of the literature. European Journal of Special Needs Education, 17(2), 129-147.

2. Avramidis, E., Bayliss, P., \& Burden, R. (2000a). Student teachers' attitudes towards the inclusion of children with special educational needs in the ordinary school. Teaching and teacher education, 16(3), 277-293.

3. Avramidis, E., Bayliss, P., \& Burden, R. (2000b). A survey into mainstream teachers' attitudes towards the inclusion of children with special educational needs in the ordinary school in one local education authority. Educational psychology, 20(2), 191-211.

4. Block, M.E., \& Obrusnikova, I. (2007). Inclusion in physical education: A review of the literature from 1995-2005. Adapted Physical Activity Quarterly, 24(2), 103-124.

5. Block, M.E., \& Rizzo, T.L. (1995). Attitudes and attributes of physical educators associated with teaching individuals with severe and profound disabilities. Research and Practice for Persons with Severe Disabilities, 20(1), 80-87.

6. Brojčin, B. (2013). Inkluzivna edukacija [Inclusive education. In Serbian]. Beograd: Fakultet za specijalnu edukaciju i rehabilitaciju.

7. Costa, P.T., \& McCrae, R.R. (1995). Domains and Facets: Hierarchical Personality Assessment Using the Revised NEO Personality Inventory. Journal of Personality Assessment, 64(1), 21-50.

8. Doulkeridou, A., Evaggelinou, C., Mouratidou, K., Koidou, E., Panagiotou, A., \& Kudlacek, M. (2011). Attitudes of Greek Physical Education Teachers towards Inclusion of Students with Disabilities in Physical Education Classes. International Journal of Special Education, 26(1), 1-11.

9. Downs, P., \& Williams, T. (1994). Student attitudes toward integration of people with disabilities in activity settings: A European comparison. Adapted Physical Activity Quarterly, 11, 32-43.

10. Folsom-Meek, S.L., Nearing, R.J., Groteluschen, W., \& Krampf, H. (1999). Effects of academic major, gender, and hands-on experience on attitudes of preservice professionals. Adapted Physical Activity Quarterly, 16(4), 389-402.
11. Đorđić, V., Tubić, T., \& Protić, B. (2014). Stavovi učitelja seoskih i gradskih škola prema inkluzivnom fizičkom obrazovanju [The attitudes of teachers of rural and urban schools to inclusive physical education. In Serbian]. Sportske nauke $i$ $z$ dravlje, 4(1), 33-40.

12. Elliott, S. (2008). The Effect of Teachers' Attitude toward Inclusion on the Practice and Success Levels of Children with and without Disabilities in Physical Education. International Journal of Special Education, 23(3), 48-55.

13. Hodge, S.R., \& Jansma, P. (2000). Physical education majors' attitudes toward teaching students with disabilities. Teacher Education and Special Education, 23(3), 211-224.

14. Hutzler, Y. (2003). Attitudes toward the participation of individuals with disabilities in physical activity: A review. Quest, 55(4), 347-373.

15. Hutzler, Y., Zach, S., \& Gafni, O. (2005). Physical education students' attitudes and self-efficacy towards the participation of children with special needs in regular classes. European Journal of Special Needs Education, 20(3), 309-327.

16. Kowalski, E.M., \& Rizzo, T.L. (1996). Factors influencing preservice student attitudes toward individuals with disabilities. Adapted Physical Activity Quarterly, 13(2), 180-196.

17. Lee, K., \& Ashton, M.C. (2004). Psychometric properties of the HEXACO personality inventory. Multivariate Behavioural Research, 39(2), 329-358.

18. Logan, B.E., \& Wimer, G. (2013). Tracing inclusion: Determining teacher attitudes. Research in Higher Education Journal, 20, 1-10.

19. O’Brien, D., Kudláček, M., \& Howe, P.D. (2009). A contemporary review of English language literature on inclusion of students with disabilities in physical education: A European perspective. European Journal of Adapted Physical Activity, 2(1), 46-61.

20. Papadopoulou, D., Kokaridas, D., Papanikolaou, Z., \& Patsiaouras, A. (2004). Attitudes of Greek physical education teachers toward inclusion of students with disabilities. International Journal of Special Education, 19(2), 104-111. 
21. Pejčić, B., Orlić, A., \& Milanović, I. (2016). Stavovi nastavnika fizičkog vaspitanja prema inkluziji dece sa razvojnim smetnjama [Attitudes of PE teachers towards inclusion of children with developmental disabilities. In Serbian]. In G. Kasum \& M. Mudrić. (eds.). Proceedings of International scientific conference "The effects of physical activity application to anthropological status of children, youth and adults, (pp.136-141). Belgrade: Faculty of Sport and PE.

22. Rizzo, T.L., \& Vispoel, W.P. (1991). Physical educators' attributes and attitudes toward teaching students with handicaps. Adapted Physical Activity Quarterly, 8(1), 4-11.

23. Scruggs, T.E., \& Mastropieri, M.A. (1996). Teacher perceptions of mainstreaming/inclusion, 1958-1995: A research synthesis. Exceptional Children, 63(1), 59-74.
24. Sibley, C.G., \& Duckitt, J. (2013). Personality geneses of authoritarianism: The form and function of Openness to Experience. In F. Funke, T. Petzel, J. C. Cohrs, \& J. Duckitt (Eds.), Perspectives on Authoritarianism (pp. 169-199). Wiesbaden, Germany: VS-Verlag.

25. Sibley, C.G., Harding, J.F., Perry, R., Asbrock, F., \& Duckitt, J. (2010). Personality and prejudice: Extension to the HEXACO personality model. European Journal of Personality, 24(6), 515-534.

26. Saucier, G. (2000). Isms and the structure of social attitudes. Journal of Personality and Social Psychology, 78(2), 366-385.

27. Tubić, T., \& Đorđić, V. (2012). Inclusive physical education in Vojvodina: The current situation and future prospects. Facta Universitatis, Series: Physical Education and Sport, 10(4), 319-327.

28. Vogel, T., \& Wanke, M. (2016). Attitudes and Attitude Change. London: Routledge.

\title{
PRÄDIKTOREN DER EINSTELLUNG VON STUDENTEN ZUR INKLUSION VON KINDERN MIT ENTWICKLUNGSSTÖRUNGEN IN DEN SPORTUNTERRICHT
}

\begin{abstract}
Zusammenfassung:
Eine positive Einstellung zur Inklusion von Kindern mit Entwicklungsstörungen in den Sportunterricht ist ein wichtiger Faktor für einen erfolgreichen inklusiven Unterricht. Ziel der Untersuchung war es, Prädiktoren der Einstellung von Studenten, zukünftiger Sportlehrer, zur Inklusion in den Sportunterricht festzustellen. Umfasst wurden Prädiktoren aus der Domäne der Persönlichkeit, der Fachkompetenzen für die Arbeit mit Kindern mit Entwicklungsstörungen und einzelner persönlicher Charakteristiken (Geschlecht). Die Untersuchung umfasste 221 Studenten des letzten Studienjahrs der Fakultäten für Sport und Sportunterricht in Belgrad, Niš und Novi Sad. Für die Messung der Einstellung zur Inklusion in den Sportunterricht wurde als Instrument die Attitude Toward Inclusive Physical Education verwendet. Aus dem Persönlichkeitsbereich wurde die Eigenschaft der Offenheit für Erfahrungen untersucht, die mit Hilfe des Instruments HEXACO PI-R gemessen wurde. Ein zusätzlicher Fragebogen mit Fragen über das Geschlecht der Studenten und die Fachkompetenzen für die Arbeit mit Kindern mit Entwicklungsstörungen wurde zusammengestellt: die durchschnittliche Note während des Studiums, subjektive Einschätzung der Wissensebene und der Fertigkeiten für die Arbeit mit Kindern mit Entwicklungsstörungen, die sie während ihres Studiums erworben haben (Eigeneinschätzung der Fachkompetenzen) und Erfahrung in der Arbeit mit Kindern mit Entwicklungsstörungen während ihrer Fachpraxis. Die Ergebnisse der multiplen Regressionsanalyse haben aufgezeigt, dass sich als bedeutende Prädiktoren Offenheit für Erfahrungen, Selbsteinschätzung der Fachkompetenzen und Geschlecht hervorheben. Die Ergebnisse weisen darauf hin, dass während der Vorbereitungen für den Lehrerberuf bei den Studenten spezifische Kompetenzen entwickelt werden sollten, die für die Arbeit im inklusiven Unterricht benötigt werden, sowie die Gestaltung eines Lehrklimas erforderlich ist, das Neugier und Kreativität als wichtige Bestimmungsprinzipien der Eigenschaft „Offenheit für Erfahrungen" unterstützt.
\end{abstract}

Schlüsselwörter: BILDUNG / PERSÖNLICHKEIT / KOMPETENZEN / SCHÜLER

Received: 19.10 .2016$.

Accepted: 09.11.2016.

() 2016 The Author. Published by Physical Culture (www.fizickakultura.com). This article is an open access article distributed under the terms and conditions of the Creative Commons Attribution license (http://creativecommons. org/licenses/by/3.0/rs/). 


\title{
ПРЕДИКТОРИ СТАВА СТУДЕНАТА ПРЕМА ИНКЛУЗИЈИ ДЕЦЕ СА РАЗВОЈНИМ СМЕТЊАМА У НАСТАВУ ФИЗИЧКОГ ВАСПИТАЫА
}

\author{
Ана Орлић, Бојан Пејчић, Душанка Лазаревић, Ивана Милановић \\ Факултет спорта и физичког васпитања, Универзитет у Београду
}

\begin{abstract}
Сажетак
Позитиван став према укључивању деце са развојним сметњама у наставу физичког васпитања (ФВ) је веома важан фактор за успешну реализацију инклузивног образовања. Циљ истраживања био је да се испитају предиктори става студената, будућих наставника ФВ, према инклузији у ФВ. Укључени су предиктори из домена личности, стручних компетенција за рад са децом са развојним сметњама и појединих персоналних карактеристика (пол). Истраживањем је обухваћен 221 студент завршних година студија Факултета спорта и физичког васпитања у Београду, Нишу и Новом Саду. За мерење става према инклузији у ФВ употребљен је инструмент Attitude Toward Inclusive Physical Education. Из домена личности испитана је особина отвореност за искуства, која је мерена инструментом HEXACO PI-R. Конструисан је и додатни упитник у коме су постављена питања о полу студената и стручним компетенцијама за рад са децом са развојним сметњама: просечна оцена током студија, субјективна процена нивоа знања и вештина за рад са децом са развојним сметњама које су стекли током студија (самопроцена стручне компетентности) и искуство у раду са децом са развојним сметњама током стручне праксе. Резултати мултипле регресионе анализе су показали да се као значајни предиктори издвајају отвореност за искуства, самопроцена стручне компетентности и пол. Током припреме за наставнички позив потребно је код студената развијати специфичне комптенције које су потребне за рад у инклузивном образовању, као и стварати наставну климу која подржава радозналост и креативност као битне одреднице, особине, отворености за нова за искуства.
\end{abstract}

Кључне речи: ОБРАЗОВАЮЕ / ЛИЧНОСТ / КОМПЕТЕНЦИЈЕ / УЧЕНИЦИ

\section{УВОД}

Позитиван став наставника према укључивању деце са развојним сметњама у редовну наставу је један од најзначајних фактора за квалитетну реализацију инклузивног образовања (Avramidis \& Norwich, 2002; Brojčin, 2013; O’Brien, Kudláček, \& Howe, 2009). Ставови наставника утичу како на комуникационе процесе у одељењу, тако и на квалитет реализације наставних садржаја који су прописани курикулумом (Logan, \& Wimer, 2013). Истраживања су показала да наставници физичког васпитања (ФВ) који имају позитивније ставове према инклузивном образовању улажу више труда у наставни процес, и резултира већим напретком деце са развојним сметњама (Elliott,
2008). Имајући ово у виду, веома је важно да се код студената, будућих носилаца инклузивног процеса, развијају позитивни ставови према инклузивном образовању.

Иако у психологији постоје различите концепције ставова, аутори се слажу да они представљају диспозиције које се могу формирати и мењати под утицајем различитих персоналних и социјалних фактора (е. g., Vogel, \& Wanke, 2016). Хацлер (Hutzler. 2003) је у прегледној студији показао да су пол, претходно искуство у раду са децом са развојним сметњама и опажена компетентност за реализацију инклузивног образовања најчешће испитивани фактори који су повезани са ставовима према инклузији код наставника и студената физичког васпитања. 
Истраживања која су се бавила повезаношћу пола и става према инклузији у ФВ нису дала доследне резултате. У једном броју истраживања је показано да наставници и студенти ФВ женског пола имају позитивније ставове према инклузији од наставника и студената мушког пола (Downs, \& Williams, 1994; Folsom-Meek, Nearing, Groteluschen, \& Krampf, 1999; Hodge, \& Jansma, 2000; Hutzler, Zach, \& Gafni, 2005; Papadopoulou, Kokaridas, Papanikolaou, \& Patsiaouras, 2004), док у неким истраживањима полне разлике нису добијене (Doulkeridou, Evaggelinou, Mouratidou, Koidou, Panagiotou, \& Kudlacek, 2011; Pejčić, Orlić, \& Milanović, 2016; Rizzo, \& Vispoel, 1991; Tubić, \& Đorđić, 2012). Иако се у литератури веома ретко могу наћи објашњења за добијене полне разлике, неки аутори сматрају да могући разлог може бити у томе што су мушкарци у већој мери оријентисани на тренажни него на наставни процес, што може створити конфликт улога при укључивању деце са сметњама у развоју у наставу ФВ, који даље води формирању негативнијих ставова према инклузији (Hutzler et al., 2005).

Аутори се слажу да је опажена компетентност за рад са децом са развојним сметњама један од важних фактора који је повезан са ставовима према инклузивном образовању (Block, \& Rizzo, 1995; Hutzler, 2003; Kowalski, \& Rizzo, 1996; Rizzo, \& Vispoel, 1991). У истраживању које су спровели Ковалски и Ризо (Kowalski, \& Rizzo, 1996) регресионом анализом је показано да је опажена компетентност најзначајнији предиктор позитивних ставова према инклузији у наставу ФВ, после које као значајан предиктор следи број факултетских курсева који су посвећени инклузивном образовању. Упоредиве резултате добили су Хацлер и сарадници (Hutzler et al., 2005) који су показали да су позитивни ставови према инклузији повезани са већим доживљајем самоефикасности у подучавању деце са развојним сметњама у ФВ. Иако извори опажене компетентности, као сложеног психолошког конструкта, могу бити различити, показано је да добра припрема студената ФВ током образовног процеса повећава доживљај компетентности и поверања у сопствене способности да се успешно реализује инклузивно образовање (O’Brien et al., 2009).

Истраживања која су се бавила личним искуством у раду да децом са развојним сметњама као фактором који је повезан са ставовима према инклузији у наставу ФВ дала су контрадикторне резултате. У неким истраживањима је добијено да наставници или студенти који су имали искуства у раду са децом са развојним сметњама имају позитивније ставове (Folsom-Meek et al., 1999), у неким да имају негативније ставове (Downs, \& Williams, 1994; Pejčić et al., 2016), док у једном סроју истраживања није добијена повезаност између искуства и ставова према инклузији (Hutzler et al., 2005; Tubić, \& Đorđić, 2012). Аутори сматрају да основни разлог за неконзистентне резултате лежи у квалитету искустава које су наставници и студенти имали током инклузивне праксе: уколико се опажа да је наставни процес под контролом и уколико резултира позитивним образовним исходима ставови постају позитивнији, а уколико се доживљава да наставни процес није под контролом, ставови остају непромењени или се погоршавају (Hutzler et al., 2005).

Претходна истраживања нису доводила у везу ставове према инклузији деце са развојним сметњама и структуру личности. Ипак, у многобројним истраживањима је показано да је структура личности важна детерминанта за развијање ставова и предрасуда. Особина личности која је у досадашњим истраживањима показала доследну везу са различитим врстама ставова је отвореност за искуства (eng. Openess to experiences). Ова особина се у савременим теоријама сматра једном од базичних димензија личности, и као таква је препозната како у петофакторском моделу личности (eng. Five factor model) (Costa, \& McCrae, 1995), тако и у НЕХАCО моделу (Lee, \& Ashton, 2004). Отвореност за искуства на свом позитивном полу обухвата радозналост, креативност, спремност да се усвоје нове, неконвенционалне идеје и развијен осећај за естетику, док на свом негативном полу обухвата конвенционалност, склоност традиционалним ставовима и уверењима, преференцију познатог над непознатим, неприхватање нових концепата и идеја и недостатак осећаја за естетику (е. g., Lee, \& Ashton, 2004). У екстензивном истраживању Саусир (Saucier, 2000) показао да је отвореност за искуства повезана са широким спектром социјалних ставова. Специфично, показано је да су особе које су затворене за искуства склоне десничарској ауторитарности (eng. Right-Wing Authoritarianism - RWA) и оријентацији ка социјалној доминацији (eng. Social Dominance Orientation - SDO), као и предрасудама према мањинским групама које се опажају као опасне, одбачене, или другачије у од- 
носу на већину (Sibley, Harding, Perry, Asbrock, \& Duckitt, 2010). Аутори сматрају да затвореност за искуства утиче на то да се свет око себе посматра као извор нових, непознатих и ризичних идеја, које прете да угрозе стабилност, што погодује развијању десничарског ауторитаризма и склоности ка социјалној доминацији. Као последица овога, развијају се негативни ставови и предрасуде према различитим врстама мањинских група (Sibley et al., 2010; Sibley \& Duckitt, 2013). Имајући ово у виду, оправдано је претпоставити да ова особина личности може бити повезана и са ставовима према инклузији деце са развојним сметњама у наставу ФВ.

Циљ овог истраживања је да се испитају предиктори ставова студената, будућих наставника физичког васпитања, према инклузији деце са развојним сметњама у наставу физичког васпитања. Укључени су предиктори из домена личности, стручних компетенција за рад са децом са развојним сметњама и појединих персоналних карактеристика (пол). Предиктор из домена личности је особина отвореност за искуства. Стручне компетенције за рад са децом која имају развојне сметње испитиване су преко просечне оцене током студија, субјективне процене нивоа знања и вештина за рад са децом са развојним сметњама које су стекли током студија (самопроцена стручне компетентности) и искуства у раду са децом са развојним сметњама.

\section{МЕТОД}

\section{Узорак испитаника}

Истраживањем је обухваћен 221 студент завршних година (четврта година основних академских и мастер студија) са три Факултета спорта и физичког васпитања у Србији. У узорак је ушло $99(44.8 \%)$ студената из Београда, 58 (26.2\%) из Ниша и 64 (29\%) студента из Новог Сада. Према полној структури, узорак је чинило 128 (57.9\%) студената мушког и 93 (42.1\%) женског пола.

\section{Инструменти и варијабле}

За мерење ставова студената према инклузији деце са развојним сметњама у наставу физичког васпитања употребљен је инструмент Attitude Toward Inclusive Physical Education - ATIPE (Hutzler et al., 2005), а који су за потребе испи- тивања на српском језику адаптирали Ђорђић и сарадници (Đorđić, Tubić, \& Protić, 2014). Овај инструмент се састоји од 15 ставки праћених четворостепеном скалом Ликертовог типа. Провера факторске структуре инструмента (анализа главних компоненти) у овом истраживању показала је једнофакторско решење, које објашњава 39\% варијансе, што оправдава рачунање општег скора на скали. Скор на скали ATIPE се изражава просечном вредношћу одговора на све ставке, а већи скор указује на позитивније ставове према инклузији деце са развојним сметњама у наставу ФВ. Поузданост инструмента (Cronbah $\alpha$ ) у овом истраживању износила је .87.

Особина отвореност за искуства мерена је инструментом HEXACO PI-R (Lee, \& Ashton, 2004). Субскала која мери ову особину састоји се од 16 ставки које обухватају четири домена: естетска осетљивост (eng. Aestethic Appreciation), радозналост (eng. Inquisitiveness), креативност (eng. Creativity) и неконвенционалност (eng. Unconventionality). Свака ставка праћена је петосепеном скалом Ликертовог типа. Скор се изражава просечном вредношћу одговора на све ставке, а већи скор означава већу отвореност за искуства. Cronbah a мера поузданости у овом истраживању износила је .81.

За прикупљање општих података о испитаницима (пол, место студирања и година студија) и њиховој стручној компетентности за рад са децом са развојним сметњама конструисан је упитник. Стручне компетенције студената процењене су преко успешности током студирања, субјективне процене нивоа знања и вештина за рад са децом са развојним сметњама које су стекли током студија (самопроцена стручне компетентности) и искуства у раду са децом са развојним сметњама. Успешност током студирања операционализована је просечном оценом. Самопроцена стручне компетентности мерена је питањем „На скали од 1 до 5 процените у којој мери сте током претходног школовања стекли знања и вештине за рад са децом са развојним сметњама?"“, где 1 значи да знања и вештине уопште нису стекли, а 5 значи да су стекли сва потребна знања. Искуство у раду са децом са развојним сметњама мерено је питањем „Да ли сте до сада, током стручне праксе или других активности на факултету, имали прилику да радите у одељењу у које је укључено дете са развојним сметњама?“" при чему су студенти одговарали са ДА или НЕ. 


\section{Поступак}

Истраживање је спроведено електронским путем (eng. online). Попуњавање упитника трајало је између 10 и 15 минута. Истраживање је било добровољно и анононимно.

\section{Обрада података}

Подаци су обрађени дескриптивном статистиком (аритметичка средина, стандардна девијациja, минимална и максимална вредност, фреквенца, проценат) и статистиком закључивања (регресиона анализа).

\section{РЕЗУЛТАТИ}

У Табели 1 приказани су резултати дескриптивне статистике (минимум, максимум, аритметичка средина и стандардна девијација) за појединачне ставке скале АTIPE. Подаци су приказани на нерекодираним вредностима. У даљим анализама, ставке које су формулисане у негативном облику су рекодиране, тако да већи скор означава позитивнији став.

Таסела 1. Дескриптивна статистика за појединачне ставке скале ATIPE

\begin{tabular}{|c|c|c|c|c|c|}
\hline ATIPE - ставке & $\mathbf{N}$ & Мин & Макс & M & СД \\
\hline $\begin{array}{l}\text { 1. Наставник физичког васпитања нема знања и вештина да подучава } \\
\text { ученике са сензомоторним сметњама. }\end{array}$ & 221 & 1 & 4 & 2.35 & 0.85 \\
\hline $\begin{array}{l}\text { 2.Не би требало укључивати ученике са инвалидитетом у редовна } \\
\text { одељења, због њиховог изгледа. }\end{array}$ & 221 & 1 & 4 & 1.57 & 0.72 \\
\hline $\begin{array}{l}\text { 3. Пошто је квалитет и ефикасност наставе физичког васпитања } \\
\text { приоритет, важно је избегавати могућа ометања, укључујући и } \\
\text { инклузију деце са сметњама/инвалидитетом. }\end{array}$ & 221 & 1 & 4 & 1.95 & 0.78 \\
\hline $\begin{array}{l}\text { 4.Деца са сметњама/инвалидитетом могу много добити учествовањем } \\
\text { у физичком васпитању са другом децом. }\end{array}$ & 221 & 1 & 4 & 3.46 & 0.64 \\
\hline $\begin{array}{l}\text { 5. Деца са сметњама/инвалидитетом често изазивају дисциплинске } \\
\text { проблеме на часу физичког васпитања. }\end{array}$ & 221 & 1 & 4 & 1.88 & 0.74 \\
\hline $\begin{array}{l}\text { 6. Наставник који укључује дете са сметњом/инвалидитетом у } \\
\text { редовни час физичког васпитања, смањује време које може да } \\
\text { посвети другим ученицима. }\end{array}$ & 221 & 1 & 4 & 2.57 & 0.88 \\
\hline $\begin{array}{l}\text { 7. Дете са сметњама/инвалидитетом може успорити учење друге деце } \\
\text { на часу физичког васпитања. }\end{array}$ & 221 & 1 & 4 & 2.30 & 0.79 \\
\hline $\begin{array}{l}\text { 8. Дете са сметњама/инвалидитетом омета наставника физичког } \\
\text { васпитања. }\end{array}$ & 221 & 1 & 4 & 1.91 & 0.71 \\
\hline $\begin{array}{l}\text { 9. Деца са сметњама/инвалидитетом треба да похађају специјална } \\
\text { одељења. }\end{array}$ & 221 & 1 & 4 & 2.56 & 0.91 \\
\hline $\begin{array}{l}\text { 10. Укључивање деце са сметњама/инвалидитетом представља лични } \\
\text { изазов за наставника. }\end{array}$ & 221 & 1 & 4 & 3.14 & 0.61 \\
\hline $\begin{array}{l}\text { 11. Наставник који укључи дете са сметњама/инвалидитетом је } \\
\text { изложен ризику већег стреса. }\end{array}$ & 220 & 1 & 4 & 2.64 & 0.77 \\
\hline $\begin{array}{l}\text { 12. Укључивање детета са сметњама/инвалидитетом може допринети } \\
\text { развијању позитивних вредности. }\end{array}$ & 221 & 1 & 4 & 3.43 & 0.68 \\
\hline $\begin{array}{l}\text { 13. Укључивање детета са сметњом/инвалидитетом у одељењу ствара } \\
\text { фрустрацију и непријатност. }\end{array}$ & 221 & 1 & 4 & 2.01 & 0.70 \\
\hline $\begin{array}{l}\text { 14. Редовно одељење може имати користи од инклузије детета са } \\
\text { сметњама/инвалидитетом. }\end{array}$ & 221 & 1 & 4 & 2.95 & 0.78 \\
\hline $\begin{array}{l}\text { 15. Није у реду тражити од наставника који треба да ради са } \\
\text { целим одељењем, да посвети посебну пажњу деци са сметњама/ } \\
\text { инвалидитетом и њиховим родитељима. }\end{array}$ & 221 & 1 & 4 & 2.48 & 0.95 \\
\hline
\end{tabular}

Леїенga. $N$ - величина узорка, Min - минимум, Max - максимум, $M$ - аритметичка средина, $S D$ - стандардна девијација 
У Табели 2 приказани су дескриптивни показатељи за скалу ATIPE у целини, особину отвореност за искуства, просечну оцену током студија и субјективну процену нивоа знања и вештина за рад са децом са развојним сметњама. Добијене вредности стандардизованог скјуниса и куртози- са показају да нема значајних одступања од нормалне диструбуције за све наведене варијабле. На питање о искуству у раду са децом са развојним сметњама 127 (57.5\%) испитаника је одговорило да је имало искуства у раду са овом децом, док је 94 (42.5\%) одговорило да није.

Табела 2. Дескриптивна статистика за став према инклузији, особину отвореност за искуства, просечну оцену током студија и самопроцену стручне компетентности

\begin{tabular}{lccccccc}
\hline & $\mathbf{N}$ & $\mathbf{M и н}$ & $\mathbf{M a \kappa c}$ & $\mathbf{M}$ & $\mathbf{C Д}$ & $\mathbf{z ~ S k}$ & $\mathbf{z ~ K u}$ \\
\hline Став (АТІРЕ) & 221 & 1.73 & 4.00 & 2.92 & 0.46 & -0.03 & -0.02 \\
Отвореност за искуства & 221 & 1.94 & 4.88 & 3.63 & 0.61 & -0.04 & -0.11 \\
Просечна оцена & 221 & 6.00 & 9.00 & 7.91 & 0.65 & 0.00 & -0.12 \\
Самопроцена стручне компетентности & 221 & 1.00 & 5.00 & 2.64 & 1.02 & 0.02 & -0.24 \\
\hline
\end{tabular}

Легенда. N - величина узорка, Мин - минимум, Макс - максимум, M - аритметичка средина, СД - стандардна девијација, z Sk - стандардизовани скјунис, z Ku - стандардизовани куртозис.

Спроведена је мултипла регресиона анализа (enter), у којој је критеријумска варијабла став према инклузији, а предикторске варијабле особина отвореност за искуства, просечна оцена током студирања, искуство у раду са децом са развојним сметњама, самопроцена стручне компетентности за рад у инклузивној настави и пол испитаника. Резултати су показали да је регресиона функција статистички значајна, $R=.38, R^{2}=.14$,
$F(5,215)=7.07, p<.01$, а као значајни предиктори су се издвојили отвореност за искуства, самопроцена стручне компетентности и пол (Табела 3). Отвореност за искуства и самопроцена стручне компетентности су позитивно повезани са ставом према инклузији, док предзнак парцијалне корелације ( $\beta$ ) између пола и става према инклузији указује на то да мушки испитаници имају позитивније ставове према инклузији од женских.

Табела 3. Мултипла регресиона анализа - парцијалне корелације и значајности за предикторе става према инклузији деце са развојним сметњама у наставу ФВ

\begin{tabular}{lccc}
\hline Предиктори & $\boldsymbol{\beta}$ & $\mathbf{t}$ & $\mathbf{p}$ \\
\hline Отвореност за искуства & .14 & 2.12 & .04 \\
Просечна оцена & -.03 & -0.52 & .61 \\
Искуство у раду & .10 & 1.5 & .14 \\
Самопроцена стручне компетентности & .29 & 4.24 & .00 \\
Пол & -.14 & -2.03 & .04 \\
\hline
\end{tabular}

Легенда. Кодови за пол: 1 - мушки, 2 - женски. Кодови за искуство у раду: 1 - да, 2 - не.

\section{ДИСКУСИЈА}

Аутори који се баве инклузивним образовањем слажу се да је позитиван став наставника према укључивању деце са развојним сметњама у редовну наставу један од кључних фактора за успешну реализацију овог процеса (Avramidis, \& Norwich, 2002; Brojčin, 2013; O’Brien et al., 2009). Узимајући у обзир да су ставови психолошке диспозиције које се могу формирати и мењати под утицајем многобројних чинилаца, различита истраживања у области ФВ су се ठавила утврђивањем фактора који су повезани са ставовима наставника и студената према инклузивном образовању. Резултати ових истраживања дали су неконзистентне резултате. Имајући ово у виду, основни циљ овог истраживања био је да се испи- 
тају предиктори става студената, будућих носилаца инклузивног процеса, према укључивању деце са развојним сметњама у наставу $Ф В$.

Резултати дескриптивне статистике су показали да студенти исказују умерено позитивне ставове према инклузији деце са развојном сметњама у наставу ФВ, што је у складу са резултатима претходних истраживања у којима је коришћена скала ATIPE, а која су спроведена на студентима (Tubić, $\&$ Đorđić, 2012), наставницима ФВ (Tubić, \& Đorđić, 2012; Pejčić et al., 2016) и учитељима (Đorđić et al., 2014). Дескриптивни показатељи одговора на појединачна питања скале ATIPE су показали да се студенти у великој мери слажу са тврдњама које истичу позитивне вредности инклузије и добробит коју деца са развојним сметњама могу имати укључивањем у редован наставни процес. Међутим, студенти се слажу и са оним тврдњама које истичу недостатак времена и ресурса потребних за квалитетан рад у одељењу у које је укључено дете са развојним сметњама. Ови резултати су такође у складу са резултатима претходних истраживања у којима је показано да наставници ФВ генерално подржавају концепт инклузије, али и да недостатак времена и ресурса истичу као главну препреку за реализацију инклузивних програма (Block, \& Obrusnikova, 2007; O’Brien et al., 2009, Pejčić et al., 2016; Scruggs, \& Mastropieri, 1996).

Предиктори става студената према инклузији деце са развојним сметњама у наставу ФВ у овом истраживању покривају домен базичне структуре личности (особина отвореност за искуства), стручних компетенција за рад са децом са развојним сметњама (просечна оцена током студирања, самопроцена стручне компетентности и искуство у раду са децом са развојним сметњама) и појединих персоналних карактеристика студената (пол). Мултипла регресиона анализа је показала да су значајни предиктори става студената: особина отвореност за искуства, самопроцена стручне компетентности и пол студената.

Досадашња истраживања нису доводила у везу ставове према инклузији деце са развојним сметњама у наставу ФВ и структуру личности. Резултати овог истраживања показују да је особина отвореност за искуства, која је дефинисана НЕXАСО моделом (Lee, \& Ashton, 2004), значајан предиктор позитивног става према инклузији. Овај резултат је у складу са резултатима студија које су показале да је негативни пол ове димензије, затвореност за искуства, повезана са склоношћу да се развију предрасуде и негативни ставови према различитим мањинским групама, између осталог и групама које се опажају као обесправљене и одбачене од стране друштвене заједнице (Sibley et. al., 2010). По мишљењу аутора, затвореност за искуства утиче на то да се свет посматра као извор нових идеја које прете да угрозе стабилност постојећег поретка, што последично утиче на развијање десничарског ауторитаризма и склоности ка социјалној доминацији, а самим тим и негативних ставова према мањинским групама (Sibley et. al., 2010). Резултати овог истраживања указују да приликом диксусије о конститутивним елементима става према инклузији треба узети у обзир и базичну структуру личности. Иако структура личности није директно подложна педагошким интервенцијама, ипак је могуће током наставног процеса створити климу која подржава радозналост и креативност студената, особине које чине срж отворености за искуства. У даљим истраживањима било би значајно проверити предиктивну вредност и других особина личности које би могле да буду од значаја за формирање позитивног става према инклузији, као што је сарадљивост (eng. Agreeableness).

Стручне компетенције студената, будућих наставника ФВ су у овом истраживању операционализоване преко просечне оцене током студирања, самопроцене стручне компетентности и искуства у раду са децом са развојним сметњама у досадашњој стручној пракси. Резултати су показали да је једини значајан предиктор из ове групе варијабли самопроцена стручне компетентности. Студенти који процењују да су током школовања стекли довољно знања и вештина које су потребне за рад са децом са развојним сметњама исказују позитивније ставове према инклузивном физичком образовању. Важно је напоменути да самопроцена стручне компетентности има највећу парцијалну корелацију са ставом према инклузији у односу на све испитиване варијабле, односно да је најважнији предиктор става према укључивању деце са развојним сметњама у наставу ФВ. Овакви резултати су у складу са резултатима претходних истраживања која су указала на велики значај опажене компетентности за рад са децом са развојним сметњама за формирање позитивног става према инклузији у наставу ФВ (Block, \& Rizzo, 1995; Hutzler, 2003; Kowalski, \& Rizzo, 1996; Rizzo, \& Vispoel, 1991). Haлаз да став према инклузији није повезан са про- 
сечном оценом током студија указује на то да су за развијање позитивног става према укључивању деце са развојним сметњама у наставу ФВ општеобразовне компетенције мање важне од развијања специфичних компетенција потребних за рад у инклузивном образовању. У прилог оваквом закључку су и резултати истраживања која су показала да је позитиван став према инклузији деце са развојним сметњама повезан са бројем факултетских курсева посвећених инклузивном образовању код студената (Block, \& Rizzo, 1995) и стручних семинара, код наставника (Avramidis, Bayliss, \& Burden, 2000a,b). Аутори сматрају да је током припреме за инклузивни процес, поред теоријских знања, веома важно студентима понудити конкретне примере и препоруке, узимајући у обзир тип и степен развојне сметње коју дете има (Hutzler, 2003).

Искуство у раду са децом са развојним сметњама у настави ФВ које су студенти имали током стручне праксе није се показало као значајан предиктор става према инклузији. Претходна истраживања која су се бавила личним искуством као фактором који може утицати на ставове према инклузији у ФВ нису дала конзистентне резултате. У неким истраживањима је показано да је лично искуство у раду са децом са развојним сметњама повезано са позитивнијим ставовима према инклузији у ФВ (Folsom-Meek et al., 1999), у неким да је оно повезано са негативнијим ставовима (Downs, \& Williams, 1994; Pejčić et al., 2016), док у једном броју истраживања није показана повезаност између искуства и става према инклузији (Hutzler et al., 2005; Tubić, \& Đorđić, 2012). Поједини аутори сматрају да овакви неконзистенти налази одражавају разлике у квалитету искустава које су наставници и студенти имали током рада са децом са развојним сметњама, а које се огледа у степену доживљаја контроле наставног процеса и образовним исходима који из њега следе (Hutzler et al., 2005). Имајући ово у виду, у наредним истраживањима би требало детаљније испитати улогу личног искуства у формирању става према инклузији у ФВ узимајући у обзир квалитет наставног процеса у раду са одељењима у која су укључена деца са развојним сметњама.

Претходна истраживања која су се бавила повезаношћу пола наставника и студената и ставова према инклузији у ФВ су показала да жене имају позитивније ставове од мушкараца (Downs, \& Williams, 1994; Folsom-Meek et al., 1999; Hodge, \&
Jansma, 2000; Hutzler et al., 2005; Papadopoulou et al., 2004), или да повезаност између пола и ставова не постоји (Doulkeridou et al., 2011; Pejčić et al., 2016; Rizzo, \& Vispoel, 1991; Tubić, \& Đorđić, 2012). Супротно од ових налаза, у овом истраживању је показано да студенти мушког пола исказују позитивније ставове према инклузији у ФВ од студената женског пола. Узимајући у обзир да је ово први налаз овог типа, добијене резултате треба проверити у даљим истраживањима.

\section{ЗАКЉУЧАК}

Резултати овог истраживања су показали да студенти, будући наставници ФВ, показују умерено позитивне ставове према инклузији деце са развојним сметњама у наставу ФВ, али и да постоји простор за њихово даље побољшање. Као значајни предиктори става према инклузији издвојили су се особина отвореност за искуства, самопроцена стручне компетентности за рад са децом са развојним сметњама и пол. Узимајући у обзир да је самопрецена стручне компетентности за рад у инклузивном образовању најзначајнији предиктор става, потребно је током процеса припреме студената за будући наставни рад развијати специфичне компетенције које су потребне за рад са децом са развојним сметњама у ФВ. Поред теоријских знања о инклузивном образовању, студентима би требало пружити конкретне примере и одговарајуће методичке поступке у раду са децом са развојним сметњама, узимајући у обзир специфичности наставе физичког васпитања. Поред овога, имајући у виду значај особине отвореност за искуства за формирање позитивног става студената према инклузивном физичком васпитању, потребно је развијати наставну климу која ће подржавати радозналост и креативност студената.

Рад је део пројеката „Ефекти примењене физичке активности на локомоторни, метаболички, психосоцијални и васпитни статус популације Р Србије” (бр III-47015) и „ Идентификација, мерење и развој когнитивних и емоционалних компетенција важних друштву оријентисаном на европске интеграције (ठp.179018) чију реализацију финансира Министарство просвете, науке и технолошког развоја Републике Србије. 


\section{ЛИТЕРАТУРА}

1. Avramidis, E., \& Norwich, B. (2002). Teachers' attitudes towards integration/inclusion: A review of the literature. European Journal of Special Needs Education, 17(2), 129-147.

2. Avramidis, E., Bayliss, P., \& Burden, R. (2000a). Student teachers' attitudes towards the inclusion ofChildren with special educational needs in the ordinary school. Teaching and teacher education, 16(3), 277-293.

3. Avramidis, E., Bayliss, P., \& Burden, R. (2000b). A survey into mainstream teachers' attitudes towards the inclusion of children with special educational needs in the ordinary school in one local education authority. Educational psychology, 20(2), 191-211.

4. Block, M.E., \& Obrusnikova, I. (2007). Inclusion in physical education: A review of the literature from 1995-2005. Adapted Physical Activity Quarterly, 24(2), 103-124.

5. Block, M. E., \& Rizzo, T.L. (1995). Attitudes and attributes of physical educators associated with teaching individuals with severe and profound disabilities. Research and Practice for Persons with Severe Disabilities, 20(1), 80-87.

6. Brojčin, B. (2013). Inkluzivna edukacija. Beograd: Fakultet za specijalnu edukaciju i rehabilitaciju.

7. Vogel, T., \& Wanke, M. (2016). Attitudes and Attitude Change. London: Routledge.

8. Doulkeridou, A., Evaggelinou, C., Mouratidou, K., Koidou, E., Panagiotou, A., \& Kudlacek, M. (2011). Attitudes of Greek Physical Education Teachers towards Inclusion of Students with Disabilities in Physical Education Classes. International Journal of Special Education, 26(1), 1-11.

9. Downs, P., \& Williams, T. (1994). Student attitudes toward integration of people with disabilities in activity settings: A European comparison. Adapted Physical Activity Quarterly, 11, 32-43.

10. Đorđić, V., Tubić, T., \& Protić, B. (2014). Stavovi učitelja seoskih i gradskih škola prema inkluzivnom fizičkom obrazovanju. Sportske nauke $i$ zdravlje, 4(1), 33-40.

11. Elliott, S. (2008). The Effect of Teachers' Attitude toward Inclusion on the Practice and Success Levels of Children with and without Disabilities in Physical Education. International Journal of Special Education, 23(3), 48-55.

12. Kowalski, E.M., \& Rizzo, T.L. (1996). Factors influencing preservice student attitudes toward individuals with disabilities. Adapted Physical Activity Quarterly, 13(2), 180-196.

13. Lee, K., \& Ashton, M.C. (2004). Psychometric properties of the HEXACO personality inventory. Multivariate Behavioral Research, 39(2), 329-358.

14. Logan, B.E., \& Wimer, G. (2013). Tracing inclusion: Determining teacher attitudes. Research in Higher Education Journal, 20, 1-10.

15. O’Brien, D., Kudláček, M., \& Howe, P.D. (2009). A contemporary review of English language literature on inclusion of students with disabilities in physical education: A European perspective. European Journal of Adapted Physical Activity, 2(1), 46-61.

16. Papadopoulou, D., Kokaridas, D., Papanikolaou, Z., \& Patsiaouras, A. (2004). Attitudes of Greek physical education teachers toward inclusion of students with disabilities. International Journal of Special Education, 19(2), 104-111.

17. Пејчић, Б., Орлић, А., и Милановић, И. (2016). Ставови наставника физичког васпитања према инклузији деце са развојним сметњама. У Г. Касум и М. Мудрић. (ур.), Зборник раgова Међунаровна научна конференција Ефекиии иримене физичке актиивностии на антиройолошки стиайус gеце, омлаgине и одраслих, Беоіраg, 11-12. Деиембар 2015, (стр.136-141). Београд: Факултет спорта и физичког васпитања.

18. Rizzo, T.L., \& Vispoel, W.P. (1991). Physical educators' attributes and attitudes toward teaching students with handicaps. Adapted Physical Activity Quarterly, 8(1), 4-11.

19. Scruggs, T.E., \& Mastropieri, M.A. (1996). Teacher perceptions of mainstreaming/inclusion, 1958-1995: A research synthesis. Exceptional Children, 63(1), 59-74.

20. Sibley, C. G., \& Duckitt, J. (2013). Personality geneses of authoritarianism: The form and function of Openness to Experience. In F. Funke, T. Petzel, J. C. Cohrs, \& J. Duckitt (Eds.), Perspectives on Authoritarianism (pp. 169-199). Wiesbaden, Germany: VS-Verlag. 
21. Sibley, C. G., Harding, J.F., Perry, R., Asbrock, F., \& Duckitt, J. (2010). Personality and prejudice: Extension to the HEXACO personality model. European Journal of Personality, 24(6), 515-534.

22. Saucier, G. (2000). Isms and the structure of social attitudes. Journal of Personality and Social Psychology, 78(2), 366-385.

23. Tubić, T., \& Đorđić, V. (2012). Inclusive physical education in Vojvodina: The current situation and future prospects. Facta Universitatis, Series: Physical Education and Sport, 10(4), 319-327.

24. Folsom-Meek, S. L., Nearing, R. J., Groteluschen, W., \& Krampf, H. (1999). Effects of academic major, gender, and hands-on experience on attitudes of preservice professionals. Adapted Physical Activity Quarterly, 16(4), 389-402.
25. Hodge, S.R., \& Jansma, P. (2000). Physical education majors' attitudes toward teaching students with disabilities. Teacher Education and Special Education, 23(3), 211-224.

26. Hutzler, Y. (2003). Attitudes toward the participation of individuals with disabilities in physical activity: A review. Quest, 55(4), 347-373.

27. Hutzler, Y., Zach, S., \& Gafni, O. (2005). Physical education students' attitudes and self-effi cacy towards the participation of children with special needs in regular classes. European Journal of Special Needs Education, 20(3), 309-327.

28. Costa, P.T., \& McCrae, R.R. (1995). Domains and Facets: Hierarchical Personality Assessment Using the Revised NEO Personality Inventory. Journal of Personality Assessment, 64(1), 21-50.

\title{
PRÄDIKTOREN DER EINSTELLUNG VON STUDENTEN ZUR INKLUSION VON KINDERN MIT ENTWICKLUNGSSTÖRUNGEN IN DEN SPORTUNTERRICHT
}

\begin{abstract}
Zusammenfassung:
Eine positive Einstellung zur Inklusion von Kindern mit Entwicklungsstörungen in den Sportunterricht ist ein wichtiger Faktor für einen erfolgreichen inklusiven Unterricht. Ziel der Untersuchung war es, Prädiktoren der Einstellung von Studenten, zukünftiger Sportlehrer, zur Inklusion in den Sportunterricht festzustellen. Umfasst wurden Prädiktoren aus der Domäne der Persönlichkeit, der Fachkompetenzen für die Arbeit mit Kindern mit Entwicklungsstörungen und einzelner persönlicher Charakteristiken (Geschlecht). Die Untersuchung umfasste 221 Studenten des letzten Studienjahrs der Fakultäten für Sport und Sportunterricht in Belgrad, Niš und Novi Sad. Für die Messung der Einstellung zur Inklusion in den Sportunterricht wurde als Instrument die Attitude Toward Inclusive Physical Education verwendet. Aus dem Persönlichkeitsbereich wurde die Eigenschaft der Offenheit für Erfahrungen untersucht, die mit Hilfe des Instruments HEXACO PI-R gemessen wurde. Ein zusätzlicher Fragebogen mit Fragen über das Geschlecht der Studenten und die Fachkompetenzen für die Arbeit mit Kindern mit Entwicklungsstörungen wurde zusammengestellt: die durchschnittliche Note während des Studiums, subjektive Einschätzung der Wissensebene und der Fertigkeiten für die Arbeit mit Kindern mit Entwicklungsstörungen, die sie während ihres Studiums erworben haben (Eigeneinschätzung der Fachkompetenzen) und Erfahrung in der Arbeit mit Kindern mit Entwicklungsstörungen während ihrer Fachpraxis. Die Ergebnisse der multiplen Regressionsanalyse haben aufgezeigt, dass sich als bedeutende Prädiktoren Offenheit für Erfahrungen, Selbsteinschätzung der Fachkompetenzen und Geschlecht hervorheben. Die Ergebnisse weisen darauf hin, dass während der Vorbereitungen für den Lehrerberuf bei den Studenten spezifische Kompetenzen entwickelt werden sollten, die für die Arbeit im inklusiven Unterricht benötigt werden, sowie die Gestaltung eines Lehrklimas erforderlich ist, das Neugier und Kreativität als wichtige Bestimmungsprinzipien der Eigenschaft „Offenheit für Erfahrungen" unterstützt.
\end{abstract}

Schlüsselwörter: BILDUNG / PERSÖNLICHKEIT / KOMPETENZEN / SCHÜLER

Примљен: 19.10.2016.

Прихваћен: 09.11.2016.

(c) 2016 Autor. Objavio Fizička kultura (www.fizickakultura.com). Ovo je članak otvorenog pristupa i distribuira se u skladu sa Creative Commons licencom (http://creativecommons.org/licenses/by/3.0/rs/). 